\title{
Harka Ödön
}

\section{A gépesített háború elméletének nyugat-európai teoretikusai a két világháború között 1. rész}

\section{The Western European Theorists of the Theory of Mechanised Warfare in the Period between the Two World Wars - Part One}

\begin{abstract}
Absztrakt
A brit Fuller tábornok tanai szerint az ellenséges erök megsemmisitésére és a győzelem gyors elérésére egyedül a hivatásos katonákból szervezett, korszerüen felszerelt harckocsiegységek képesek, amelyek állandó harckészültségben állnak, így bármikor képesek megkezdeni a hadmüveleteket. Az úgynevezett tömeghadseregek csupán a siker kifejlesztésében, a harckocsik által elfoglalt terepszakaszok biztositásában játszhatnak szerepet. A szintén brit Liddell Hart által vált híressé az úgynevezett „közvetett megközelítés" elmélete, amelynek értelmében a siker nem elsősorban frontális támadásra alapozva érhetö el. A döntéseik során a vezetöknek figyelemmel kell lenniük az alternatív-konkrét és áttételes - lehetöségekre is. Ezzel szemben von Seeckt tábornok az 1929-es munkájában még a versailles-i békeszerződés által meghatározott keretekhez igazodva fogalmazta meg a nézeteit a jövő háborújával kapcsolatosan, elképzelései a modernizált lovasságban, a lovas-magasabbegységek fejlesztésének szükségességében öltöttek testet. A történelem azonban nem az ö, hanem a brit katonai stratégák gépesítéssel kapcsolatos jövőképét igazolta.
\end{abstract}

Nemzeti Közszolgálati Egyetem Hadtudományi Doktori Iskola, doktorandusz - National University of Public Service, Doctoral School of Military Sciences, PhD student, e-mail: odon.harka@eulerhermes.com, ORCID: https://orcid. org/0000-0002-4195-1262 
Kulcsszavak: Liddell Hart, Fuller, von Seeckt, mély hadmüvelet, hadmüveleti lépcsö, áttörés, gépesitett hadviselés

\begin{abstract}
According to the British General Fuller's approach, only those well-equipped tank units with professional soldiers are able to destroy the enemy forces and thus to achieve quick victory, that are constantly ready to fight so they can begin the fighting operations at any time. The so called "mass armies" can play a role in the success development and in securing the terrain sections captured by tank units. The theory of the "indirect approach" was made famous by the British General Liddell Hart under which the success is not primarily based on frontal assault. The leaders have to take into consideration during the course of their decisions the alternative - the actual and the referral - possibilities. Contrary to the above, the German General von Seeckt, in his work from 1929 defined his views on the war of the future, even within the frames defined by the Versailles Peace Treaty. His ideas were manifested in the need of the development of cavalry units. History verified the assumptions of the British strategists, instead of his views.
\end{abstract}

Keywords: Liddell Hart, Fuller, von Seeckt, deep operation, operational stage, breakthrough, mechanised warfare

\title{
John Frederick Charles Fuller ${ }^{2}$
}

A két világháború közötti időszak legnevesebb angol katonai gondolkodója John Frederick Charles Fuller tábornok volt. Meglátása szerint az első világháború legfontosabb tanulsága, hogy a tömeghadseregek ideje lejárt, az ellenfél megsemmisítésére, a gyors győzelem kivívására a speciális technikával és képzettséggel bíró harckocsiés gépesített csapatok képesek. ${ }^{3}$

Fuller tábornok gépesített hadviselésre vonatkozó föbb elképzeléseit több, e tárgyban írt tanulmánya mellett a Harckocsik az 1914-1918 közötti nagy háborúban címü könyvében, illetve az 1932-ben közreadott, a Gépesített erök hadmüveletei címü munkájában publikálta. ${ }^{4}$ Fuller tanai szerint az ellenséges erők megsemmisítésére és a győzelem gyors elérésére egyedül a hivatásos katonákból szervezett, korszerüen felszerelt harckocsiegységek képesek, amelyek állandó harckészültségben állnak, így

Fuller, John Frederick Charles (1878-1966) vezérörnagy, hadtörténész és teoretikus. Katonai ismereteit a sandhursti Királyi Katonai Akadémián, illetve a Camberley-i Törzsakadémián szerezte. Szigetországi, dél-afrikai és indiai szolgálat után, az első világháborúban a honi erőknél töltött be törzstiszti beosztást, majd Franciaországban harcolt a 7. hadtest állományában, illetve 1916-tól a Géppuskás Hadtest (a későbbi „Tankhadtest”) főparancsnokságán. Mint hadtest vezérkari fönök, ő dolgozta ki az 1917. évi cambrai harckocsitámadás, valamint az 1918. őszi offenzíva terveit. Bár a teljesen gépesített hadseregre vonatkozó - 1919-ben megalkotott - elképzelése soha nem valósult meg, különböző fontos vezetői beosztást látott el, mint az aldershoti kísérleti dandár parancsnoka. John Frederick Charles Fuller, Wikipédia, http:// en.wikipedia.org/wiki/J._F._C._Fuller (Letöltve: 2019. 01. 18.)

Lengyel Ferenc: Katonapolitika és hadművészet a két világháború között, Zrínyi Miklós Katonai Akadémia, $1972,54$. Uo. 
bármikor képesek megkezdeni a hadmüveleteket. Az általános mozgósítás eredményeképpen megalakuló, úgynevezett tömeghadseregek az áttörésben nem, csupán a siker kifejlesztésében, a harckocsik által elfoglalt terepszakaszok biztosításában játszhatnak szerepet. Az ideális harckocsihadsereg szervezetét a következőképpen képzelte el:

- harckocsi és páncéltörő wing alkotja az alapegységet, ami felderítőharckocsi-, tüzérharckocsi- (önjáró lövegek) és rombolóharckocsi-alegységekből áll;

- a páncéltörő wing gépvontatású páncéltörő lövegekből és gépágyúkból álló alegységekből épül fel;

- a tartalék viszont könnyűharckocsi-, fegyvernemi és szakalegységekből áll, feladata pedig az üldözés. ${ }^{5}$

Fuller tábornok szerint a háborúk három alapeleme a csapásmérés (amelynek képességét a felszerelés, valamint a fegyverzet biztosítja), az elhárítás (a képességet a védekezőeszközök garantálják), továbbá a mozgás (szállítóeszközökkel), amely tényezők egymástól nem elválaszthatók, a fegyverzet és védekezés függ a mozgástól. A katonai (mozgási) tevékenységek szintén három halmazra oszthatók: beszélhetünk hadászati, harcászati, illetve adminisztratív (mozgási) tevékenységről. A harcászati, illetve az adminisztratív tevékenységek támadó és védekező mozgásokra bonthatók, így a katonák által végrehajtott védekezőtevékenységek nemcsak oltalmazó jellegűek, hanem annál sikeresebbek, minél inkább elősegítik a támadó manővereket. A hadászat lényegét az angol teoretikus abban látta, hogy adott esetben egy egész hadsereget szükséges olyan helyzetbe hozni, hogy a harcászati mozgásokat a lehetőség szerint az erők legtakarékosabb felhasználása mellett hajtsa végre. ${ }^{6}$

A fegyverzet célja az ellenség megsemmisitése, megsebzése, illetve demoralizálása, felhasználása során ügyelni szükséges arra, hogy a nagy hatótávú fegyverek fedezzék a kisebb hatótávolságú eszközöket, illetve megkönnyítsék azok alkalmazását. ${ }^{7}$

A védekezőtevékenység a tábornok szerint megvalósulhat közvetlen vagy közvetett módon. A közvetett védelem az ellenoldal csapásait nem akadályozza meg, csupán korlátozni képes azt, például a saját eszközök álcázásával, illetve csapások mérésével. A katonák közvetlen statikus védelméről az erődítések, a páncélzat gondoskodik, a közvetlen mozgó védekezés kategóriájába pedig a harckocsik tartoznak. Ez utóbbiak alkalmazása mellett a repülőgépek felfegyverzése megnyitotta a hadmúvészet új dimenzióját a szó szoros és átvitt értelmében is. ${ }^{8}$

\section{A gépesített támadás elmélete}

Fuller tábornok - elfogadván a clausewitzi definíciót - a (gépesített) háború valódi céljaként a politika érveinek szavakon túlmenő, (katonai) erővel történő támogatását

Uo.

Szemelvények a XIX. század burzsoá katonai teoretikusainak és szakíróinak müveiből 3. Liddell Hart, Fuller, de Gaulle, in: Száva Péter (szerk.), A páncélos háború elméletének képviselői, Zrínyi Miklós Katonai Akadémia, Budapest, 1972, 107-108.

Szemelvények (1972): i. m. 109.

Szemelvények (1972): i. m. 110. 
határozta meg, a harc végső célját azonban nem az ellenség anyagi megsemmisítésében, hanem annak morális megtörésében, alávetésében vélte felfedezni. A háborús taktikáknak és stratégiáknak kell a nyers erő helyébe lépniük, az „idegek harcának” szükséges helyettesítenie az anyagi források és élőerő elleni küzdelmet. Az eljövendő harcok a mozgékony, páncélozott ágyú (harckocsi) megjelenésének köszönhetően az első világháborúban tapasztaltakhoz képest megváltoznak és átalakulnak a harckocsik egymás közötti harcává. ${ }^{9}$

A mozgékonyság az ütközet jellegét is átalakítja, a kétdimenziós küzdelem miatt az arcvonal már nem képes egymagában oltalmazni a mögöttes területeket, a támadások több irányból is bekövetkezhetnek, így növekszik a meglepetés ereje. Fuller tábornok a gyalogos- és a harckocsizó-egységeket tekintette a két fö fegyvernemnek, erre tekintettel a harc területét e két fegyvernem alkalmazási lehetőségeinek megfelelően vélte szükségesnek meghatározni, és fegyvernemek szerint elkülönült (gyalogos-, illetve harckocsi-) zónákra gondolta felosztani. A gépesített erők támadó célú alkalmazását megelőzően a támadó fél feladata az, hogy az ellenséges erők mozgását megakadályozza, vagy legalábbis korlátozza. ${ }^{10}$

A gépesített egységek harcászati lehetőségei kapcsán a tábornok az alábbiakat hangsúlyozta:

- az arctámadás csak kivételes esetekben alkalmazható, viszont amennyiben lehetséges, úgy a harctér meghatározott terepszakaszait kell elfoglalni, amelyek feletti ellenőrzés megszerzése az ellenséges erőket a terveik módosítására kényszeríti;

- a megbízható felderítési adatok és az ezekre épülő műveletek, valamint az ellenséges parancsnokság feletti pszichológiai befolyás megszerzése együttesen szolgálhatnak a siker zálogául;

- az egyes fegyvernemek bevetési körleteit minden esetben a terepviszonyokhoz szükséges igazítani;

- az ellenséges erőket folyamatosan mozgásban kell tartani, és törekedni kell azok kifárasztására, tartalékainak (üzemanyagának) felélésére.11

\section{A gépesített védelem kérdése}

A gépesített hadviselésben a harc megvívásának művészete a támadó- és védekezőtevékenységek szoros összekapcsolásán alapul. Mindkét alapmanőver sikeressége a felderítésen múlik. A gépesített háborúban három zóna létezik:

- a mély, hadászati zóna;

- a kevésbé mély harcászati zóna, valamint

- a keskeny biztosítási zóna. ${ }^{12}$

Szemelvények (1972): i. m. 121.

Szemelvények (1972): i. m. 122-123.

Szemelvények (1972): i. m. 124.

Szemelvények (1972): i. m. 131-132. 
A hadászati mélyzóna felderítésének és harcának elsődleges eszközei a repülőcsapatok, míg a harcászati zónában tevékenykednek a gépkocsizó és motorkerékpáros egységek, a harmadik zónában pedig a harckocsik és gépesített gyalogoscsapatok. ${ }^{13}$

A szerző a védelem két típusát különböztette meg: az ellenállást (egy adott állás megtartása) és az örzésvédelmet (örzési és megfigyelési feladatokkal), amely utóbbi kategória három részre tagolható: az elkülönült parancsnokság alatt álló elővéd, oldalvéd és utóvéd. Az őrzésvédelem szervezése területén Fuller tábornok alapvetö változtatásokat tartott szükségesnek, mivel álláspontja szerint a feladatokat gépesített gerillaszázadoknak kell majd ellátniuk, amelyek egységes parancsnokság alatt állnak. ${ }^{14}$

Az ellenállás (állásvédelem) jellemzői a kitüzött feladat függvényében változhatnak. Így, beszélhetünk egy terepszakasz (bázis) védelméről és utánpótlásának biztosításáról, az ellenség végleges megállításáról, illetve az ellenséges elöretörés ideiglenes megállításáról. A védekezőtevékenység megszervezése során is szükséges tekintetbe venni a terepadottságokat. Az ellenséges csapatok időleges megállítása esetében törekedni kell a harcrendjének oldalról vagy hátulról való bomlasztására, valamint arra, hogy a védekezőtevékenység kifejtése lehetőséget biztosítson a gyorsan mozgó egységek számára a szétbontakozásra. A védelem általános tervének minden esetben számolnia kell azzal, hogy szükségesek lehetnek a harckocsik elleni védelmi munkálatok, illetve lehetővé kell tennie az ellentámadásra alkalmas, gyorsan mozgó harcrendi elemek integrálását. ${ }^{15}$

A páncéltörő fegyvereket a védelemben oly módon szükséges elhelyezni, hogy a tüzükkel képesek legyenek a támadó gépesített (harckocsi-) egységeket visszaverni egészen addig a pontig, amelyet a saját tüzérség már képes lefogni. A tüzérségi lövegek a harckocsikat visszavonulásra kényszerítik a saját harckocsik ellentámadására kijelölt terepszakaszig, az ellenlökéseket végrehajtó harckocsik pedig aknamezőre üldözik az ellenséges jármúveket. ${ }^{16}$

\section{Basil Henry Liddell Hart}

Az első világháború lezárultát követően a brit hadsereg megszabadult a technikai eszközeinek jelentős részétöl (nehéztüzérség, harckocsik), a brit vezérkar egy kis létszámú és korszerüen felszerelt fegyveres erő létrehozását tüzte ki célul. A szárazföldi haderőnemmel kapcsolatos angol megfontolásokat erősen determinálták NagyBritannia természetföldrajzi adottságai, az ország szigetjellege és a Brit Birodalom (Nemzetközösség) világhatalmi státuszának fenntartásához füződő igény. A katonai teoretikusokat a fenti megfontolások elsősorban a tengerekhez, a tengeri jelenléthez (kereskedelmi útvonalak biztosítása, a mandátumuk alatt álló korábbi gyarmati területekkel való kapcsolattartás) kötötték, Nagy-Britannia stratégiai helyzete pedig garantálta az angol hadvezetés számára azt, hogy egy esetleges újabb európai fegyveres konfliktusba a nekik kedvező időpontban léphessenek be.

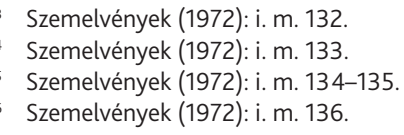


A brit Liddell Hart ${ }^{17}$ által vált híressé az úgynevezett „közvetett megközelítés” elmélete, amelynek értelmében a siker nem elsősorban frontális (arc-) támadásra alapozva érhető el (legyen bármekkora erőfölény a támadó oldalán). A döntése során a parancsnoknak figyelemmel kell lennie az alternatív (kerülő) utakra, egyrészt a konkrétakra (szárnyfelgöngyölítés, a mozgékonyságra épített kikerülés, hátba támadás, a súlypontképzés, a döntő ütközet elöl való kitérés, az ellenség kifárasztása, utánpótlási vonalaik elvágása), akár az áttételes lehetőségekre (szövetségi rendszerek fellazítása, váratlan politikai eszközök alkalmazása, „ötödik hadoszlop”18 beépítése). Emlékiratok címü, 1965-ben megjelent művében a szerző bemutatta a brit fegyveres erők korszerűsítése érdekében végzett tevékenységét és a gépesített hadviseléssel kapcsolatos nézetrendszerének kialakulását. ${ }^{19}$

A szerző a gépesített hadviseléssel kapcsolatos nézeteit már egy 1919-ben megjelent írásában kifejtette, miszerint a jövőbeni fejlődés irányvonalaként a mozgékony könnyügyalogság és a harckocsik integrált kötelékben megvalósuló együttműködését képzelte el. Liddell Hart - kortársához és barátjához - Fullerhez hasonlóan képzelte el a jövő hadszíntereit, azonban míg Fuller számára a harckocsik tömeges alkalmazása ultima ratióként jelent meg (a gyalogság kizárólag a harckocsik által birtokba vett terület megszállására alkalmazható), Liddell Hart arra az álláspontra helyezkedett, hogy a gépesített gyalogos- és harckocsizóegységek együtt, egymást segítve vívják meg harcaikat, a motorizált gyalogság segíti a harckocsikat a védett akadályok leküzdése során. ${ }^{20}$

A szerző már a Royal United Service Institution ${ }^{21} 1922$-es pályázata kapcsán írt dolgozatában is hangsúlyozta, hogy a következő háborút a gépesített egységek harcai fogják eldönteni. Legfontosabb következtetése az volt, hogy a lovasegységek harcra és felderítésre is alkalmatlanok, a konfliktusok végkimenetelét az összhaderőnemi (szárazföldi erők és légierő), valamint összfegyvernemi (harckocsik, gyalogság és tüzérség) együttmüködés minősége dönti majd el. Liddell Hart arra is rámutatott, hogy a tüzérség legütőképesebb egységei az önjáró alvázra helyezett lövegek lesznek, illetve sürgette a légi szállítás és légi utánpótlás eszközeinek a fejlesztését is. A harckocsikat már ekkor 84 mm ürméretü löveggel látta célszerűnek felszerelni. ${ }^{22}$

Liddell Hart „térítő" tevékenysége és a technikai fejlődés (a harckocsik növekvő sebessége, hatótávolsága) megtette a hatását a kortárs teoretikusokra, illetve magukra

17 Liddell Hart, Basil Henry (1895. 10. 31.-1970. 01. 29.) az első világháború végén századosként szerelt le a brit hadseregből, katonai szakiró és hadtörténész. A harckocsik és a mozgó hadviselés jelentőségét felismerve síkra szállt az angol hadsereg modernizációjáért. Jelentősebb művei Az 1914-18-as világháború története (1930), illetve a Stratégia (1954). B. H. Liddell Hart, Wikipédia, https://en.wikipedia.org/wiki/B._H._Liddell_Hart (Letöltve: 2019. 01. 20.)

18 Az ötödik hadoszlop kifejezés a spanyol polgárháború idején vált ismertté, olyan csoportosulást jelent, amely katonai konfliktus vagy politikai válság idején saját országának érdekeit egy idegen hatalom javára árulja el, az ellenoldalt propagandával, kémkedéssel, szabotázzsal segíti. Ötödik hadoszlop, www.arcanum.hu/hu/online-kiadvanyok/Lexikonokmagyarorszag-a-masodik-vilaghaboruban-lexikon-a-zs-F062E/o-o-F0C85/otodik-hadoszlop-F0CB4/ (Letöltve: 2019. 01. 20.)

19 Szemelvények (1972): i. m. 3.

20 Szemelvények (1972): i. m. 10.

21 Védelmi és biztonsági kérdésekkel foglalkozó angol tanácsadó szervezet (agytröszt). 1831-ben Wellington hercege, Sir Arthur Wellesley alapította meg. A szervezet (RUSI) független, kormányzathoz, pártokhoz nem köthetö. Royal United Services Institute, https://rusi.org/about-rusi (Letöltve: 2019. 01. 20.)

22 Szemelvények (1972): i. m. 11. 
a katonákra is. A szerző harckocsik alkalmazásával kapcsolatos elméleti elképzeléseit az 1933-ban Percy Hobart dandártábornok parancsnoksága alatt megalakult brit 1. harckocsidandár részvételével megtartott, 1934-es hadgyakorlat visszaigazolta, azonban a bemutatott új módszereket elsősorban a német Wehrmacht tette magáévá. A gyakorlat megmutatta, hogy az egyes hadseregeknek a rendelkezésükre áll az az eszköz, amely képes lehet az állóháborút újra „mozgásba hozni”. Világossá vált továbbá, hogy a jövő háborújában ismét a támadási manőverek fognak elsőbbséget élvezni, a támadóeszközök (harckocsik) pedig megújult technikájú (mozgékony eszközökre támaszkodó) védelemmel fognak szembenézni. Liddell Hart tehetségét és nyitott gondolkodását igazolta az a tény is, amely szerint ő már az 1920-as évek vége óta a harckocsik alkalmazásának lehetséges jövőbeni területeként, illetve az újabb nyugat-európai háború potenciális felvonulási, illetve hadszíntereként kezelte az Ardennek térségét. ${ }^{23}$

Az 1. harckocsidandár felállítása során teljesen újszerü szervezési modellként létrehozták a dandár önálló ellátóoszlopát, amely lehetővé tette, hogy több napra elegendő élelem, üzemanyag és lőszer álljon a csapatok rendelkezésére, így függetlenné váljon a dandár a saját ellátóvonalaktól. A hadgyakorlat értékelésében Hobart tábornok külön kiemelte a harckocsik és a repülőgépek együttmüködésének fontosságát, ennek ellenére az RAF (Brit Királyi Légierő) szakemberei az önálló légi hadászat doktrínáját követve igyekeztek minimalizálni a szárazföldi csapatokkal való együttmüködést. A szervezeti fejlesztések csúcsaként 1935-ben megalakult az első brit „mozgékony hadosztály” az 1. harckocsidandárból, a részben már gépesített 7. gyalogdandárból, egy gépesített tábori tüzérosztályból, egy páncélosfelderítő-ezred egységeiből, illetve egyéb kisegítő alegységekből. ${ }^{24}$

\section{Johannes Friedrich Leopold von Seeckt}

Von Seeckt ${ }^{25}$ porosz lovassági tábornok 1929-ben közzétett Egy katona gondolatai címü munkájában még a versailles-i békeszerződés által meghatározott keretekhez (harckocsik alkalmazásának tilalma), valamint a harckocsik pillanatnyi technikai és gyártási állapotához igazodva fogalmazta meg a nézeteit a jövő háborújával kapcsolatosan. A korszerü haditechnikán a szerző elsősorban a légierő eszközeit értette, noha a harmadik dimenziós haderőnem nem képes a szárazföldi haderőnem helyettesítésére. A jövő háborúja von Seeckt tábornok szerint a szembenálló felek légierőinek támadásával kezdődik majd, elsődleges célpontként az ellenoldal légiereje szolgál, majd a légi fölény megszerzését követően kerülhetnek a támadások fókuszába az egyéb célpontok (városok, gyárak stb.). A repülőerők támadását szorosan követik időben

\footnotetext{
Szemelvények (1972): i. m. 41.

Szemelvények (1972): i. m. 43-45.

25 Johannes Friedrich Leopold von Seeckt (1866. 04. 22. - 1936. 12. 27.) porosz tábornok, az első világháborúban August von Mackensen tábornok vezérkari fönökeként teljesített szolgálatot. A háborút követően 1926-ig a német vezérkar fönöke volt. 1929-ben jelentette meg Egy katona gondolatai címü könyvét, középpontjában az úgynevezett „kis hadsereg” elméletével, amely jól kiképzett és gyors manőverekre képes.

Hans von Seeckt, Wikipédia, https://de.wikipedia.org/wiki/Hans_von_Seeckt (Letöltve: 2019. 01. 20.)
} 
a szárazföldi (hivatásos és kisebb létszámú) erők műveletei, amelyek bevetése után kerülhet sor - szükség esetén - a tömegerök alkalmazására. ${ }^{26}$

A kis létszámú, úgynevezett „fedező" hadsereget önkéntes hivatásos állomány alkotja, amelynek mérete az adott állam anyagi, ipari lehetőségeihez, területéhez és földrajzi helyzetéhez igazodik. $E$ hadsereggel szemben három követelmény érvényesül: a mozgékonyság, amelyet a nagy létszámú lovasegységek és azok motorizációja garantálnak, a nagy hatékonyságú fegyverzet és az utánpótlás állandósága. A vezérezredes szerint a fedező hadseregen kívül a hadvezetésnek gondoskodnia kell egy azzal együttműködő, tisztekből, altisztekből és legénységből álló olyan magról, amely képes gondoskodni az adott földrajzi területen élő népesség fiataljainak kiképzéséről, azaz a tömeghadsereg professzionálisabbá tételéről. ${ }^{27}$

A tábornok 1929-ben még a modernizált lovasságban látta a korszerü mozgóharc (elsősorban közelfelderítés) eszközét, a gépjárművek katonai alkalmazásának jelentőségét pedig egyrészt egy új fegyvernem (harckocsicsapatok) létrehozásában, másrészt a tüzérségi lövegek mozgatásában és az utánpótlás szállításában vélte megtalálni, amelyek növelik a lovashadosztályok ütőképességét. ${ }^{28}$

Számára az alap (gyorsan mozgó) lovas magasabbegység a lovashadosztály, amely három lovasdandárból (dandáronként két ezreddel) épül fel. A lovashadosztály harcait három könnyủ tábori üteg, műszaki és híradócsapatok támogatják. A messze nyúló (mélységi) feladatok végrehajtása során a lovashadosztályokat a gyalogosegységeknek támogatniuk szükséges, amely gyalogsági támogató tevékenység lendülete motorizálással tartható fenn, illetve gyorsítható. A nagyobb földrajzi mélységben folytatni kivánt müveletek eredményességéhez elengedhetetlen az egyes, különböző fegyver- és haderőnemekhez tartozó egységek közötti rádió-összeköttetés biztosítása, az utánpótlás mennyisége pedig a lovashadosztályok részére meghatározott feladatok függvényében változik. ${ }^{29}$

\section{Felhasznált irodalom}

Szemelvények a XIX. század burzsoá katonai teoretikusainak és szakíróinak műveiből 3. Liddell Hart, Fuller, de Gaulle, in: Száva Péter (szerk.), A páncélos háború elméletének képviselői, Zrínyi Miklós Katonai Akadémia, Budapest, 1972.

Lengyel Ferenc: Katonapolitika és hadművészet a két világháború között, Zrínyi Miklós Katonai Akadémia, 1972.

\section{Internetes források}

B. H. Liddell Hart, Wikipédia, https://en.wikipedia.org/wiki/B._H._Liddell_Hart (Letöltve: 2019. 01. 20.)

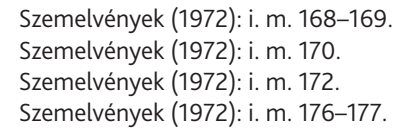


Hans von Seeckt, Wikipédia, https://de.wikipedia.org/wiki/Hans_von_Seeckt (Letöltve: 2019. 01. 20.)

John Frederick Charles Fuller, Wikipédia, http://en.wikipedia.org/wiki/J._F._C._Fuller (Letöltve: 2019. 01. 18.)

Ötödik hadoszlop, www.arcanum.hu/hu/online-kiadvanyok/Lexikonok-magyarorszaga-masodik-vilaghaboruban-lexikon-a-Zs-F062E/o-o-F0C85/otodik-hadoszlopFOCB4/ (Letöltve: 2019. 01. 20.)

Royal United Services Institute, https://rusi.org/about-rusi (Letöltve: 2019. 01. 20.) 